\title{
Research Article https://doi.org/10.33484/sinopfbd.634931 \\ A Study About The Synergy of Polar Fractions of Pomegranate Peel and Amoxicillin Trihydrate Against Enterococcus faecalis
}

\author{
Ayşegül HOŞ ${ }^{a^{*}}$, Hilal KUDAY ${ }^{b}$, Kenan TUNÇc, Alican Bahadır SEMERCÍ \\ ${ }^{a}$ Istanbul Medipol University, School of Pharmacy, Department of Basic Pharmaceutical Sciences, \\ Beykoz, İstanbul, 34815, Turkey \\ ${ }^{b}$ Ístanbul Yeni Yüzyll University, Faculty of Pharmacy, Department of Organic Chemistry İstanbul, \\ Turkey \\ ${ }^{c}$ Sakarya University, Faculty of Arts and Science, Department of Biology, Sakarya, Turkey
}

\begin{abstract}
The increase in the occurrence of the multidrug-resistant bacteria is the cause of need in the discovering new antimicrobial substances and antimicrobial combination drugs. The aim of this study was to investigate the synergistic interaction between polar fractions of pomegranate (Punica granatum L.) peel and Amoxicillin trihydrate against Enterococcus faecalis. In the first step of the study, polar fractions of pomegranate peel (ethyl acetate, butanol, distilled water) were prepared. Next, disc diffusion method was used for determination of the synergic effect. Here, the results indicated that the mixture of prepared polar fractions of pomegranate peel and Amoxicillin trihydrate showed synergistic interaction against $E$. faecalis. This study determined that polar fractions of pomegranate peel (ethyl acetate, butanol, distilled water) improved the effectiveness of Amoxicillin trihydrate against E. faecalis. Pomegranate peel may have potential applications in the new antibacterial therapy combinations due to its easy accessibility, therapeutic properties and being low cost. Results of the present study may be beneficial for further studies about the characterization of phytochemical compounds that are responsible for the improvement of the antibiotic effectiveness.
\end{abstract}

Keywords: Amoxicillin trihydrate, antibacterial activity, pomegranate, synergy

\section{Nar Kabuğu Polar Fraksiyonlarının ve Amoksisilin Trihidratın Enterococcus faecalis Üzerindeki Sinerjistik Etkisi Hakkında Bir Çalışma}

$\ddot{\mathbf{O z}}$

Çoklu antibiyotik direncine sahip bakterilerin ortaya çıkışındaki artış nedeniyle yeni antimikrobiyal maddelerin ve antimikrobiyal ilaç kombinasyonlarının keşfedilmesine ihtiyaç duyulmaktadır. Bu çalışmanın amacı, nar (Punica granatum L.) kabuğu polar fraksiyonları ile Amoksisilin trihidrat arasındaki sinerjistik etkileşimin Enterococcus faecalis üzerinde araştırılmasıdır. Çalışmanın ilk adımında, nar kabuğunun polar fraksiyonları (etil asetat, butanol, distile su) hazırlanmıştır. Sonraki aşamada sinerjik etkinin belirlenmesi için disk difüzyon yöntemi kullanılmıştır. Hazırlanan nar kabuğu polar fraksiyonları ile Amoksisilin trihidrat karışımının, E. faecalis üzerinde sinerjistik etkisinin olduğu gözlemlenmiştir. Bu çalışma, Amoksisilin trihidratın E. faecalis üzerindeki etkinliğini nar kabuğunun polar fraksiyonlarının (etil asetat, butanol, distile su) arttırdığını belirlemiştir. Nar kabuğu, kolay

${ }^{*}$ Sorumlu Yazar: ORCID ID: orcid.org/0000-0001-5605-6159

Received: 23.10 .2019

e-mail: aysegulhos@medipol.edu.tr

Accepted: 22.05 .2020 
erişilebilirliği, terapötik özellikleri ve düşük maliyeti nedeniyle yeni antibakteriyal tedavi kombinasyonlarında potansiyel uygulamalara sahip olabilir. $\mathrm{Bu}$ çalışmanın sonuçları, antibiyotik etkinliğini arttıran fitokimyasal bileşiklerin karakterizasyonu ile ilgili daha ileri çalışmalar için yararlı olabilir.

Anahtar Kelimeler: Amoksisilin trihidrat, antibakteriyal aktivite, nar, sinerji

\section{Introduction}

The multiple antibiotic resistance of pathogen microorganisms is a serious medical problem. Therefore, the improving of antibiotic efficacy has a great importance. According to the World Health Organization (WHO), traditional medicines are used by $80 \%$ of people living in developing countries. Approximately $25 \%$ of drugs prescribed worldwide are plant origin [1].

Antimicrobial compounds derived from plants have been found to be synergistic enhancers. Although they may not possess any antimicrobial properties alone, they enhance the activity of the drugs when used concurrently with standard drugs [2]. The word "synergy" derived from the Greek word "syn-ergo" is defined as the resulting effect which is significantly greater than the sum of its parts. The therapeutic value of synergistic interactions has been known since antiquity. Many different cultural healing systems rely on the combination therapy that enhanced the efficacy. In the antimicrobial synergy, the combination may enhance efficacy, reduce toxicity, decrease adverse side effects, increase bioavailability, lower the dose and reduce the advance of antimicrobial resistance. Recently, investigation of antimicrobial combination drugs have become priority [3].

Punica granatum which is belongs to Punicaceae family [4] is a shrub or a small tree [5]. The members of Punicaceae originated mainly in Iran and spread to the Himalayas and the Mediterranean region of Europe [6]. The antimicrobial properties of $P$. granatum including antifungal, antibacterial and antiviral were investigated in a number of in vitro studies. Pomegranate consumed in the Middle East for thousands of years [7] has medicinal value and ethnomedical history [8]. Peel, root bark and leaves of $P$. granatum are a good source of secondary products [9]. Pomegranate is a rich source of bioactive compounds [10]. It has been indicated that punicalagin is the responsible substance for the antimicrobial activity of the pomegranate $[11,12]$.

Food and Agriculture Organization (FAO) has been stated that pomegranate production is about 1.5 million tons all over 
the World. Large volume of wastes is produced in the course of the industrial processing of pomegranate. Therefore, in the recent years, the industrial by-products of pomegranate which have a high potential of biological properties are attracted attention of scientists [13]. It has been reported that pomegranate peel extracts possess a wide range of biological activities such as abortifacient, analgesic, antiamoebic, antibacterial, anticonvulsant, antifungal, antimalarial, anti-mutagenic, antiviral, antispasmodic, diuretic, hypoglycemic, hypothermic, and antioxidant activities [14]. Pomegranate peel was selected for this experimental study because of the fact that being low cost material and possess therapeutic value. The purpose of this study was to investigate the synergistic interaction of polar fractions of Punica granatum L. peel with Amoxicillin trihydrate against Enterococcus faecalis.

\section{Materials and Method}

\section{Materials}

Punica granatum L. fruits were purchased from a market in Sakarya, Turkey in October 2017. Test microorganism used in this study was Enterococcus faecalis ATCC 29212 which was obtained from Microorganism Culture Collections of Microbiology Research
Laboratory of Biology Department in Sakarya University, Sakarya, Turkey. Chemical solvents were provided from Sigma Aldrich.

\section{Preparation of Punica granatum Peel Fractions}

Pomegranate peels dried in shade for 7 days were ground by using an electric mill [15]. $10 \mathrm{~g}$ of pomegranate peel powder were weighed by high precision digital laboratory scale (Radwag AS 220/C/2). The polar fractions of Punica granatum peel were prepared using the procedure reported by Mtunzi et al. with minor modifications [16]. The methanol-distilled water mixture was prepared at a rate of 70:30 (v/v). The obtained peel powder of Punica granatum L. was added at a rate of 1:10 (w/v) to methanol-distilled water mixture and was kept for 3 days in a dark place. Methanol which is in the extract was evaporated by using rotary evaporator (Heidolph Laborota 4000 efficient) under vacuum at $40-45^{\circ} \mathrm{C}$ for 10 minutes. After the evaporation of methanol, aqueous extract was transferred to the separatory funnel. Then, $300 \mathrm{~mL}$ of hexane was added to the separatory funnel and shaken. The aqueous phase discharged from the bottom of the funnel. The same extraction procedures were carried out for ethyl acetate, petroleum ether and butanol, respectively. After the extraction processes, 
fractions of hexane, ethyl acetate, petroleum ether, butanol, distilled water were obtained. The thin layer chromatography (TLC) analyses of the obtained fractions were carried out to detect the presence of the constituents in the fractions. The aqueous extract was used as reference material. The running of compounds on the TLC plate were observed only for ethyl acetate, butanol and distilled water. For this reason, the synergistic interaction between Amoxicillin trihydrate and fractions of ethyl acetate, butanol and distilled water were investigated in the experiments. The solvents in the fractions were removed by evaporation process. After these processes, the fractions of ethyl acetate and butanol were prepared at the determined concentrations $(6400 \mu \mathrm{g} / 10 \mu \mathrm{L})$ by adding methanol. However distilled water fraction was prepared at the determined concentration $(6400 \mu \mathrm{g} / 10 \mu \mathrm{L})$ by adding distilled water.

Preparation of Overnight Culture of Enterococcus faecalis

Enterococcus faecalis used as test microorganism in this study were inoculated to Tryptic Soy Broth (Merck) and were incubated at $37^{\circ} \mathrm{C}$ for 24 hours. The bacterial suspension was prepared from overnight culture of Enterococcus faecalis and was adjusted to $0.5 \mathrm{McF}$ arland by using a densitometer.

\section{Determination of Synergistic Interaction}

between Polar Fractions and Amoxicillin

\section{Trihydrate}

Disc diffusion method was used for the determination of synergistic interaction between polar fractions and Amoxicillin trihydrate $[17,18]$. Amoxicillin trihydrate solution was prepared by dissolving $10 \mathrm{mg}$ of Amoxicillin trihydrate in $10 \mathrm{~mL}$ of DMSO. Firstly, $1 \mathrm{~mL}$ of polar fraction $(6400 \mu \mathrm{g} / 10 \mu \mathrm{L})$ and $1 \mathrm{~mL}$ of Amoxicillin trihydrate solution $(1 \mathrm{mg} / \mathrm{mL})$ were mixed to obtain mixture at a rate of $1: 1(\mathrm{v} / \mathrm{v})$. Then, sterile disc (6 $\mathrm{mm}$ in diameter, Rotilabo) were impregnated with $10 \mu \mathrm{L}$ of the prepared polar fraction-antibiotic mixture. Methanol impregnated discs and DMSO impregnated discs were used as negative control. Also, polar fraction (3200 $\mu \mathrm{g} / 10 \mu \mathrm{L}) \quad$ impregnated discs and Amoxicillin trihydrate $(0.5 \mathrm{mg} / \mathrm{mL})$ impregnated discs were used in the experiments to compare with the mixture of polar fraction-Amoxicillin trihydrate. The impregnated discs were allowed to dry for 24 h. 0.5 McFarland E. faecalis suspension was inoculated to Mueller Hinton Agars by using sterile swabs. The impregnated discs were pressed onto the inoculated agars and incubated at $37^{\circ} \mathrm{C}$ for $24 \mathrm{~h}$. After the 
incubation period, the inhibition zone diameters (IZs) were measured. The experimental studies were carried out three times under aseptic conditions. The inhibition zone diameters were the average of three replicates.

\section{Results and Discussion}

The synergistic interaction between polar fractions of pomegranate peel (ethyl acetate, butanol and distilled water) and
Amoxicillin trihydrate against E. faecalis were investigated in this study. In the experimental process, the determination of synergistic effect was performed by using disc diffusion method. The diameters of the inhibition zone (IZs) are given in Table 1. It was observed that methanol impregnated discs and DMSO impregnated discs which are used as negative control have not formed inhibition zone.

Table 1. Synergistic interaction between polar fractions of Punica granatum L. peel and Amoxicillin trihydrate against $E$. faecalis

\begin{tabular}{|c|c|c|c|c|}
\hline \multirow[t]{2}{*}{ Bacterium } & \multicolumn{3}{|c|}{ Diameters of the inhibition zone (IZs) (mm) } & \multirow[t]{2}{*}{ Synergy } \\
\hline & $\begin{array}{l}\text { Polar } \\
\text { Fraction }\end{array}$ & $\begin{array}{l}\text { Antibiotic solution } \\
\text { dissolved in DMSO }\end{array}$ & $\begin{array}{c}\text { Polar Fraction+ } \\
\text { Antibiotic }\end{array}$ & \\
\hline \multirow[b]{2}{*}{ E. faecalis } & Ethyl acetate & $\begin{array}{c}\text { Amoxicillin } \\
\text { trihydrate+DMSO }\end{array}$ & $\begin{array}{c}\text { Ethyl acetate+ } \\
\text { Amoxicillin trihydrate }\end{array}$ & \multirow[b]{2}{*}{+} \\
\hline & 0 & $8.8 \pm 0.1$ & $10.5 \pm 0.2$ & \\
\hline \multirow[b]{2}{*}{ E. faecalis } & Butanol & $\begin{array}{c}\text { Amoxicillin } \\
\text { trihydrate+DMSO }\end{array}$ & $\begin{array}{c}\text { Butanol+ } \\
\text { Amoxicillin trihydrate }\end{array}$ & \multirow[b]{2}{*}{+} \\
\hline & 0 & $8.6 \pm 0.2$ & $11.0 \pm 0.1$ & \\
\hline \multirow[b]{2}{*}{ E. faecalis } & Distilled water & $\begin{array}{c}\text { Amoxicillin } \\
\text { trihydrate+DMSO }\end{array}$ & $\begin{array}{c}\text { Distilled water+ } \\
\text { Amoxicillin trihydrate }\end{array}$ & \multirow[b]{2}{*}{+} \\
\hline & 0 & $9.0 \pm 0.1$ & $10.5 \pm 0.2$ & \\
\hline
\end{tabular}

Polar fractions of pomegranate peel (ethyl acetate, butanol and distilled water) have not been showed antimicrobial activity against E. faecalis. However, they improved the antimicrobial activity of the
Amoxicillin trihydrate against E. faecalis when used together with Amoxicillin trihydrate. According to this results, it has been concluded that the synergistic interaction occurred between Amoxicillin 
trihydrate and polar fractions of pomegranate peel (ethyl acetate, butanol, distilled water).

The investigation about synergistic interaction between polar fractions of $P$. granatum and antibiotics was not found in the literature. However, the studies about synergistic effects of Punica granatum extract and antibiotics are highly limited. In the study performed by Malik et al., the synergistic effects of the ethyl acetate extract of $P$. granatum fruit peel with Amikacin, Ampicillin, Ciprofloxacin, Erythromycin,Linkomycin, Nitrofurantoin, Tetracycline and Trimethoprim against $S$. aureus, S. epidermidis, S. hominis, E. coli and $P$. aeruginosa were investigated. The combination of Tetracycline and extract was found to possess synergistic effect with a significant decrease in minimum inhibitory concentration (MIC). Also, the extract in combination with Lincomycin was found to have a synergistic effect on $S$. aureus, S. epidermidis, S. hominis, E. coli and $P$. aeruginosa [19]. In another study, the synergistic interactions between methanolic extract of Punica granatum fruit and Chloramphenicol, Gentamicin, Ampicillin, Tetracycline and Oxacillin against MRSA (methicillin-resistant Staphylococcus aureus) and MSSA (methicillin-sensitive Staphylococcus aureus) were determined. Braga et al. reported that Punica granatum methanolic extract enhanced the activity of all antibiotics tested [20]. In a similar study, Lakshmi et al. investigated the synergistic effects of combination of Punica granatum methanolic extract and Tetracycline, Amoxicillin, Erythromycin, Cefuroxime, Cephalosporin, Penicillin G, Oxacillin, Methicillin against methicillin-resistant $S$. aureus. According to the results, the MIC values of antibiotic-extract combinations were found to be significantly reduced compared to the MIC values of antibiotics [21]. Also, Dey et al. determined that the combination of Ciprofloxacin and Punica granatum peel methanolic extract has synergistic effect on extended-spectrum $\beta$ lactamase producing Escherichia coli, Klebsiella pneumoniae and metallo- $\beta$ lactamase producing Pseudomonas aeruginosa [22]. According to the literature search, our study is the first study investigating of the synergistic interaction between Amoxicillin trihydrate and polar fractions of Punica granatum L. peel.

\section{Conclusions}

The increase in multiple antibiotic resistance has led to increase in the studies about investigating new antimicrobial agents or to enhancement the effectiveness of present antibiotics. The knowledge 
obtained from literature proved that Punica granatum peel extract shows synergistic effect when used in combination with certain antibiotics. However no study has not been found about the synergistic interaction between polar fractions of pomegranate peel and Amoxicillin trihydrate. Therefore, our investigation which is about the synergy of mixture of polar fractions of pomegranate peel and Amoxicillin trihydrate is the first study. Although polar fractions of pomegranate peel (ethyl acetate, butanol and distilled water) have not been possessed antimicrobial activity alone, it has been determined that they enhanced the antimicrobial activity of the Amoxicillin trihydrate against $E$. faecalis when used together with Amoxicillin trihydrate. As a result, our data clearly demonstrate that there are synergistic interactions between Amoxicillin trihydrate and polar fractions of pomegranate peel (ethyl acetate, butanol, distilled water). Furthermore, due to being an agro-industrial waste, pomegranate peel is low cost raw material. Pomegranate peel may be suitable for new antibacterial therapy combinations due to both its therapeutic properties and its easy accessibility. This study provide significant basis for the future exploration of phytochemical compounds that are responsible for the enhancement of the antibiotic efficacy.

\section{References}

[1] Ahmad I, Zahin M, Aqil F, Hasan S, Khan MSA, Owais M, 2008. Bioactive compounds from Punica granatum, Curcuma longa and Zingiber officinale and their therapeutic potential, Drugs of the Future, 33(4): 329-346.

[2] Aiyegoro OA, Okoh AI, 2009. Use of bioactive plant products in combination with standard antibiotics: Implications in antimicrobial chemotherapy, Journal of Medicinal Plants Research, 3(13): 11471152.

[3] Vuuren S, Viljoen A, 2011. Plant-based antimicrobial studies-methods and approaches to study the interaction between natural products, Planta Medica, 77(11): 1168-1182.

[4] Viuda-Martos M, Fernández-López J, Pérez-Álvarez JA, 2010. Pomegranate and its many functional components as related to human health: A review, Comprehensive Reviews in Food Science and Food Safety, 9(6): 635-654.

[5] Stover E, Mercure EW, 2007. The pomegranate: A new look at the fruit of paradise, Hortscience, 42(5): 1088-1092

[6] Ali K, Khan S, Khan N, Khan W, Rahman IU, Ullah F, Ali K, Nisar M, 2017. Ethnobotanical and ecological study of Punica granatum in Dir district, Khyber Pakhtunkhwa, Pakistan, Regulatory Mechanisms in Biosystems, 8(4): 656-661.

[7] Johanningsmeier SD, Harris GK, 2011. Pomegranate as a functional food and 
nutraceutical source, Annual Review of Food Science and Technology, 2(1): 181201.

[8] Wadhawan R, Reddy Y, Sharma R, Solanki G, 2015. Punica granatum; ancient seeds for modern cure in medical and dental field: An overview, International Journal of Traditional System of Medicine, 2(1): 1-8.

[9] Mirdehghan SH, Rahemi M, 2007. Seasonal changes of mineral nutrients and phenolics in pomegranate (Punica granatum L.) fruit, Scientia Horticulturae, 111(2): 120-127.

[10] Li Y, Guo C, Yang J, Wei J, Xu J, Cheng S, 2006. Evaluation of antioxidant properties of pomegranate peel extract in comparison with pomegranate pulp extract, Food Chemistry, 96(2): 254-260.

[11] Machado TB, Leal ICR, Amaral ACF, Santos KRN, Silva MG, Kuster RM, 2002. Antimicrobial ellagitannin of Punica granatum fruits, Journal of the Brazilian. Chemical Society, 13(5): 606-610.

[12] Rosas-Burgos EC, Burgos-Hernández A, Noguera-Artiaga L, Kačániová M, Hernández-Garcia F, Cárdenas-López JL, Carbonell-Barrachina AA, 2016. Antimicrobial activity of pomegranate peel extracts as affected by cultivar, Journal of the Science of Food and Agriculture, 97(3): 802-810.

[13] Mohamad TGM, Khalil AA, 2015. Effect of agriculture waste: pomegranate (Punica granatum L.) fruits peel on some important phytopathogenic fungi and control of tomato damping-off, Journal of Applied Life Sciences International, 3(3): 103-113.
[14] Al-Rawahi AS, Edwards G, Al-Sibani M, Al-Thani G, Al-Harrasi AS, Rahman MS, 2014. Phenolic constituents of pomegranate peels (Punica granatum L.) cultivated in Oman, European Journal of Medicinal Plants, 4(3): 315-331.

[15] Moradi M-T, Karimi A, Alidadi S, Saedi-Marghmaleki M, Salehian M, 2015. In vitro Anti-adenovirus activity of pomegranate (Punica granatum L.) peel extract, Advanced Herbal Medicine, 1(4): $1-8$.

[16] Mtunzi FM, Ejidike IP, Ledwaba I, Ahmed A, Pakade VE, Klink MJ, Modise SJ, 2017. Solvent-solvent fractionations of Combretum erythrophyllum (Burch.) leave extract: Studies of their antibacterial, antifungal, antioxidant and cytotoxicity potentials, Asian Pacific Journal of Tropical Medicine, 10(7): 670-679.

[17] Hoş A, Tunç K, 2019. Enhancement of antibacterial effectiveness of amoxicillin trihydrate and ampicillin-sulbactam, Eskişehir Technical University Journal of Science and Technology C- Life Sciences and Biotechnology, 8(1):92-97.

[18] Semerci AB, İnceçayır D, Mammadova V, Hoş A, Tunç K, 2020. Antimicrobial activities of Allium staticiforme and Allium subhirsutum, Bangladesh Journal of Pharmacology, 15(1): 19-23.

[19] Malik A, Bai S, Seasotiya L, Bharti P, Dalal S, 2014. Antibacterial and synergistic efficacy of Punica granatum ethyl acetate extract against multidrug resistant bacterial strains, American Journal of Advanced Drug Delivery, 2(4): 522-533. 
[20] Braga LC, Leite AAM, Xavier KGS, Takahashi JA, Bemquerer MP, ChartoneSouza E, Nascimento AMA, 2005. Synergic interaction between pomegranate extract and antibiotics against Staphylococcus aureus, Canadian Journal of Microbiology, 51(7): 541-547.

[21] Lakshmi AV, Harasreeramulu S, Raju DVVS, 2013. Assessment of antibacterial potential of selected medicinal plants and their interactions with antibiotics on MRSA in the health care workers of Visakhapatnam hospitals, Journal of Pharmacy Research, 6: 589-592.

[22] Dey D, Debnath S, Hazra S, Ghosh S, Ray R, Hazra B, 2012. Pomegranate pericarp extract enhances the antibacterial activity of ciprofloxacin against extendedspectrum $\beta$-lactamase (ESBL) and metallo$\beta$-lactamase (MBL) producing Gramnegative bacilli, Food and Chemical Toxicology, 50: 4302-4309. 